\title{
TRAVELLING BETWEEN LANGUAGES AND CULTURES: IN MEMORIAM ANTOANETA RALIAN
}

\author{
D A N A B A D U L E S C U \\ Alexandru Ioan Cuza University of Iasi, Romania
}

\begin{abstract}
This article, originally a talk on Antoaneta Ralian's fairly recently published memoirs, is a tribute to our most accomplished and venerated translator from English into Romanian, who started from the big dream of traveling around the world, pursuing and fulfilling it through turning her life into a quest where traveling and translating gave her the greatest joy of living. Hers were times when, during the communist regime in Romania, only the happy few could travel. Ralian was of those few: she traveled (west and east) as a translator, and traveling she translated from one culture into another. Quoting extensively from the book in the light of what made Ralian's life so rich, I argue (implicitly) that translation itself is a journey and an intercultural activity which shapes and transforms the translator's personality. In an even broader anthropological sense, it is an essential bridge built across two languages, two cultures and (as Ralian understood it) two persons: the author and the translator.
\end{abstract}

Keywords: memoirs, traveling, journey, reading, translation

I don't believe in the end of the world, but I know that pleasant things come to an end quickly. Mind you, the world is a fairly pleasant place, and it would be such a shame if we lost it (Ralian interview).

As I am writing today, Antoaneta Ralian is no longer of this world. She passed away in the evening of 26 November 2015, at 91 years old. However, the more than one hundred books she translated from English into Romanian and the optimism of her message to the world will endure. In June 2015 I gave a talk within the "Going East" Conference on Travel and Intercultural Communication in Europe, while Ralian was still living, and both then and now my sense is that of a tribute to an accomplished and venerated translator, who was also an exemplary woman of courage and dedication and a passionate traveller.

On 17 May 2014 Ralian's Amintirile unei nonagenare: Călătoriile mele, scriitorii mei [Memoirs of a Woman in Her Nineties: My Travels, My Writers] published in Bucharest by Humanitas Press was launched. The book is woven around the archetype of the journey. Life itself is a journey, but for Ralian 
traveling was a dream of youth, in which each journey enhanced it, giving it meaning, color and weight:

I want to listen to concerts conducted by great masters, I want to see magnificent theater halls with their golden and crimson loges, I want to attend posh English suppers, where they do the same ritual as in Queen Victoria's times, I want to go dancing in Broadway dancing clubs, I want to go to the Harlem boozes and listen to Negro music. I'd like to puff on opium, folded into the plies of a kimono; I want to bury myself in the Oxford libraries; I want to hang around and get lost in the Louvre for a whole month. I want to navigate on a yacht, I want to be invited to the man-of-war of a baronet descended from William of Conqueror, and study his armory; and at dusk, I want to listen to the fading out serenade of a gondolier. Oh, I want all that and even more, I do, I do (Ralian 2014, 13-14). ${ }^{1}$

That is a dream which translates an unquenched zest of life, which Ralian wanted to experience through all her senses when she was 25 . The dream also translates a desire to embrace the world, with its cultures, languages, books, arts and ages. At the same time this desire is sublime, a mode of excess characteristic of a restless spirit. Indeed, Ralian projected these fantasies onto a world into which she wanted to rejoice as a newly married woman:

Life beside you, my darling, but with a lot of voyages, with new and interesting people, shifting landscapes, the seas of the world (I've never been on a boat), elegant ships, music and gentlemen in white tailcoats, the ruins of Athens and the sunshine of Alexandria, the foul-smelling poetry of Venice, the whirling emotions of the Monte Carlo roulette, the vitiated atmosphere in the Parisian boîtes, the green color of Tyrol's feathered hats. The obsolete waltz-scented Vienna (13)

These are excerpts from her diary where she looked into what it felt like starting the life of a married woman. Ralian kept that diary for one year, and she chose these colorful and lively passages, which are the entry for 1949 New Year's Eve, as a "Preamble" to her Memoirs. The passages feel charged with the most fantastic desires of a young traveler who sets out to explore the world in its most essential aspects. That year looks like the onset of a journey, both literally and metaphorically. The onset is also archetypal: Ralian's dreams and enthusiasm feel like those of every young woman who welcomes experience in all its beauty and richness. And as if beauty and richness were not enough, she projects more beauty and richness with every new line of the entry to achieve an effect of the sublime of living as a journey.

The way she depicts life as a series of journeys, Ralian's Memoirs reads like a travelogue. Life seems to be worth living in as much as it is worth traveling. That may also be because traveling abroad was a cherished privilege

\footnotetext{
${ }^{1}$ All passages from Ralian's Memoirs are my translation.
} 
only few people were granted during the communist regime in Romania, and in the whole communist bloc. For her, Vienna was the place of her "first waltz," as it was "the first trip to the West, the first contact, in the 1960s, with the West which they kept telling me was decadent, putrid, on the edge of disaster and ready to fall" (23). The impact was as strong as it could be: the iron curtain rose, and the stage she saw was most pleasant. In Vienna of all places she discovered the magic of billboards, the bounty of a small food store, a "warm, almost paternal" trade (25), lovely little cafés, glamorous opera performances (attended by courtesy of Ioan Holender, who was later to become the art director of the George Enescu Festival). Vienna, her "first waltz," was followed by other trips to the West, each with its colors, sights, tastes and flavors, with its sounds and music, but no other place gave Ralian "that sense of Heimisch (which was there, maybe, only in my imagination), that warm sense of at home, of bonhomie, of a waltzing vibration" (27), though she could not help thinking that it was the same Austria which gave the world both Freud and Hitler.

When she renders glimpses of some of her traveling experiences, The Memoirs lapses into a book of Joycean epiphanies or Woolfian "moments of being." A few hours of music in a place reached by climbing thirty-two steps, which turns the whole experience into an archetypal quest for beauty, are a treasure which only the soul can hold:

At Menton, on the French Riviera, we spent two weeks at an Italian friend's summer house. And it just so happened that there was an international festival of classic music. It was outdoors, on the very large esplanade in front of the cathedral standing on a hill, where you would get climbing thirty-two broad moss-covered stone steps. And so every night we would go all the way up and listen to Georges Prêtre conducting Respighi's Roman Trilogy, to Repin in Mendelssohn Bartholdi's Violin Concerto, and to many more. To listen to classical music under the starry sky, in front of a Gothic cathedral with all its stained-glass windows lit, on the top of a hill, with the dark sea lapping sleepily underneath, with fishermen's boats graciously gliding through the waves is ... I needn't say what it is like (82-83).

In 1973 Ralian was invited to London for two weeks by the British Council, recommended by the British Embassy of Bucharest. That was a reward for her numerous translations from English literature. Apart from the stress of having to be on time for the various appointments with editors, writers and cultural personalities, and having to be intelligible in English, which "is a lot more difficult than being intelligible in your own language" (29), Ralian cherished that visit because she had a chance to meet Iris Murdoch in a pub. Almost forty years after that encounter, Ralian had a vivid memory of Murdoch's physiognomy, which she described as "an Irish visage, with short bangs, high and rosy cheekbones, slightly slanting eyes and a smile like warm 
bread" (31). That was the beginning of a friendship which lasted twenty five years.

As years went by, Ralian had yet other chances to revisit London. To her mind, "revisiting London, one has a sense that it is a city where everything lasts, everything is immovable and it continues untrammeled, beyond one's agitated and fragmented time. The same riders in colored tunics and shining boots take a walk along the riding alleys in Hyde Park, and the Tower of London listens to the horror stories of its past, told mechanically by the same Beefeaters dressed in the costumes of the age, as if cut out from the labels of whiskey bottles of that name" (33-34).

It is precisely because the notes of Ralian's memoirs date that the whole book, with its patina, is so distinctly charming. For any Romanian reader who has lived during the communist regime, it is very obvious that her fascination with the lavish Christmas decorations on Oxford Street, and the punk youth who mean to challenge and shock the establishment, but fail to do so because Londoners had already been used to shocking generations of Beatles fans and hippies, are set in sharp contrast to a Romania of grey impressions. Apart from these, Ralian had an eye and an appreciation for the British sense of an unbroken line of tradition and history, which is expressed in their almost ritualistic changing of the guards at the Buckingham Palace. However, as she noticed, in winter the performance "is less spectacular and colorful: the blazing red uniforms and Scottish tartans are now camouflaged under grey cloaks," but the guards "parade in the same stately rhythm, in unison, like mechanical lead soldier toys, set in motion by the tune played by the brass band" (36). In St. James Park, Green Park, Hyde Park, and Kensington, the famous English turf keeps its "fresh moist green"; here and there the eye is taken by "big roses like puffed cabbages; December roses; a lonely rider on the Serpentine," and although Big Ben and the statue of Eros might be in "temporary refurbishment," "the calm, relaxing massiveness of London is unaltered" (36-37).

In Ralian's view, reading is a way of traveling, a leap of the imagination, which gives you knowledge of and familiarity with the place, reinforced by actual traveling. Thus, she confessed in her memoirs that London looked familiar because she knew it from the books she had translated, from Defoe's Journal of the Plague Year to Galsworthy's trilogy End of the Chapter. Likewise, the Villa of San Michèle looked familiar because, while still a child, her mother used to account for everything she read, translating it in a child's language; or the house on Menton Street where Katherine Mansfield spent a few years of her terminal illness, and where she could find her own translations from the writer's Diary; or the Trois Couronnes hotel in Vevey, Switzerland, the spitting image of the hotel in Henry James's Daisy Miller. The translator argues that the recognition of those places, rendered familiar by reading, increases the emotion of seeing them in actual life. 
Translation itself is a journey. For Ralian, most of her trips to the West were translation missions, but the etymology of the word itself is equated with a journey. In the fourteenth century it meant: "to remove from one place to another," and also "to turn from one language to another." The word entered the English language from the Old French term "translater," which in Latin was "translatus" meaning "carrying over." Like any journey, translation transforms the translator, or so Ralian accounts for it. The process of translating Henry Miller's Trilogy looks like a journey in which the shy translator, whose tongue would have gone stiff at uttering "naked words", is transformed almost unawares:

as I was making my way through the book, translating it, and especially when I reached the Trilogy, my embarrassment vanished, and I even started to feel that Miller was working like a charm on me: I reached a total and spontaneous linguistic lack of inhibition, a freedom from taboos, and even more than that, somehow I reached some sort of voluptuousness (157).

For Ralian, translating was the supreme experience, one in which living, traveling, reading and writing joined. In an interview she confessed that "When I work, when I translate, when I put myself into the lives of others, into another world, I forget that my legs hurt, I forget that my back aches, nothing else matters" ("Visez foarte mult şi foarte frumos"). Indeed, translation was such a complete experience for Ralian that it enhanced the self's sense of being:

I and myself, i.e. the demanding critic watching me translate, and the writer make a perfect duality of three, like a triangle of love. I, alter ego and altera pars, but without altering the text's essence (152).

Such a joy is translation that it does not really matter that the translator's role is "passive, always eclipsed, a second violin"; ultimately, the translator is the author's "friend," taking pains "to capture peculiarities and nuances, to render the fluency and brightness meant to ensure the Romanian reader's appreciation" (151-152).

Indeed, the translator's job is to bridge the gap not only between two languages, but also between two cultures. In order to do so, a good translator must be, in the first place, a good reader. As Michaela Wolf argued, learning to translate means "learning to read" - to produce meanings that are acceptable for the reader's culture (Wolf 128). Thus, translation is an intercultural activity. In an even broader anthropological sense, it is an essential bridge built across two languages, two cultures and (as Ralian understood it) two persons: the author and the translator. It was this sense of connection achieved through translation which made Ralian's encounters with the actual writers whom she met, either traveling or at home, so memorable, and the friendships themselves so enduring. Maybe the friendship of her life was with Iris Murdoch. Ralian accounts for it as 
"a friendship of correspondence and visits on both sides, which lasted 25 years" (32) during which she translated four of Murdoch's novels and two of her plays, staged in Bucharest and Timişoara.

When she recalls the encounters with "her writers" in The Memoirs the book turns into a gallery of vivid pictures. Thus, Ted Hughes was "the man you'd die or rather live for", who struck Ralian as "the archetype of the Poet; handsome, ineffably sad, shy, vulnerable, introverted" (134). Her first impression of Kurt Vonnegut was that of "an explosive, eruptive, very talkative, very jovial fellow, always talking about himself, himself, himself." (136). Raymond Federman had a "Latin structure and an exuberant, communicative, vibrant spirit" (110), and Saul Bellow, whom she met in Bucharest in 1977, was "a little man who suggested frailty and vulnerability" (111). Some other times, as when she met Salman Rushdie in Bucharest in November 2009, Ralian confessed to the writer himself that "there had been passages where I fell in love with him - well, not exactly him, but his character Rai, who is, probably, a projection of him. And I added that in other passages I hated him because he would force me to leap from Nirvana peaks to rock 'n roll" (143).

Putting Ralian's Memoirs down in regret at having reached the end of the journey, I thought that translating and traveling had made her the delightful writer that she was ninety years old. Both journeys had brought her sensitivity and imagination to a ripe maturity, and there she was, at the very end of the road, looking at the world behind and into the world beyond. In her words, it would be such a shame if we lost the world, and nobody can predict what would happen, but reading Ralian's Memoirs one knows that the world was not lost on her.

\section{Works Cited}

Ralian, Antoaneta. Amintirile unei nonagenare. Călătoriile mele, scriitorii mei. Bucharest: Humanitas, 2014. Print.

Ralian, Antoaneta. "Visez foarte mult şi foarte frumos". Interviu cu Antoaneta Ralian. ObservatorCultural.ro, Web. 25 May 2015.

Wolf, Michaela. "Translation as a Process of Power: Aspects of Cultural Anthropology in Translation." Translation as Intercultural Communication. Ed. Mary SnellHornby, Zuzana Jettmarová, Klaus Kandi. 123-33. Amsterdam: John Benjamins, 1997. Print. 


\section{NOTES ON CONTRIBUTORS}

Laurence Raw writes on adaptation studies both in book form and on two blogs at http://baskent.academia.edu/LaurenceRaw and www.laurenceraw.blogspot.com. His most recent book published with University of Wisconsin Press is Six Turkish Filmmakers (2016). He is currently working on a major work of adaptation theory, unifying psychology, literature, film, and media studies, for Palgrave. In his spare time he teaches in the Department of English at Başkent University, Ankara, Turkey, where he regards his pedagogic practice as a vital component in adaptation research.

Dana Bădulescu holds a $\mathrm{PhD}$ in Philology following the defense of the thesis "Impressionistic Modes and Metaphoric Structures in E. M. Forster's Fiction and Criticism". She teaches modernist and postmodernist British and American literature, basic elements of literary theory and critical thinking, transculturalism, poetics and translations. She has translated books of history, philosophy, poetry, literary theory, international relations, and, most recently, Bill Bryson's Down Under published in 2014, and Edward Hirsch's How to Read a Poem and Fall in Love with Poetry, which came out in 2015. She has published a series of articles on modernism and postmodernism, key modernist and postmodernist writers and texts. She authored a textbook on modernism, a textbook on the nineteenth and twentieth century British novel and a book on postmodernism. Between October 2010 and March 2013 she was the receiver of a POSDRU postdoctoral grant for a project on Salman Rushdie and democracy. Since 2010 her research has been focusing on today's migrancy, hybridity, transnationalism and transculturalism. In December 2014, she formed a national research network which joined ISCH COST Action IS 1404 "Evolution of reading in the age of digitisation (EREAD).” Her most recent book Rushdie's Cross-pollinations was published in 2013.

Oana Cogeanu, $\mathrm{PhD}$, teaches English literature, cultural studies and translation studies at Alexandru Ioan Cuza University of Iași, Romania. She authored an Introduction to African-American Travel Literature (2013); edited volumes in cultural studies (Wounded Bodies, Wounded Minds, 2014) and on intercultural issues (Travel and Intercultural Communication in Europe, 2016); and published articles on a range of authors and topics, with a special interest in African-American literature and a constant focus on travel writing. She gave lectures in cultural and translation studies at universities in several European countries and taught Romanian language, civilisation and culture in South Korea.

Sorina Georgescu, PhD Lecturer at the Hyperion University, Bucharest. Defended her doctoral thesis on Slavery and Abolitionism in 19th Century American and Romanian Literary and Socio-Political Writings: A Comparative Cultural Approach, at the University of Bucharest in 2014. She is editor-in-chief of the HyperCultura biannual journal (published since 2012 by the Department of Letters and Foreign Languages at the Hyperion University). Teaches English for Specific Purposes (Journalism, Psychology, Law). Her research areas are: slavery-abolitionism-multiculturalism, 
nationalism, imagology, identity, comparative approaches. She is a member of the RAAS, EAAS and SRS societies.

Raluca Goleșteanu, $\mathrm{PhD}$ in Historical Sciences of 'Tadeusz Manteuffel' Institute of History-PAN, Warsaw. Currently works in the project Phantom Borders-Real Boundaries. European Experiences after 1989 through a Global Perspective developed by the Chair of South-East European History/Humboldt University, Berlin. The areas of interest include but are not restricted to ideologies of Central and Eastern Europe; urban landscape in transformation: the fin-de-siècle city of Central and Eastern Europe; the post-industrial features of the city; Jewish intellectuals of Galicia and Moldavia; the political role that literature played in fin-de-siècle Central and Eastern Europe; anthropology of space.

Vassilis Letsios is an Assistant Professor at the Department of Foreign Languages, Translation and Interpreting of the Ionian University (Corfu, Greece) on Modern Greek Literature and Literary Translation into Greek. He has published the monograph The Ghost Behind the Arras: transformations of the "political verse" in twentieth-century Greek poetry (Scholars' Press, 2013), as well as papers on free verse and versification, literary translation, travel writing etc. He is currently working on a second monograph entitled Poetry and Translation: The Heptanesian School and co-editing a study on travel writing entitled Oskar Emil Tudeer. The last Athenian.

Andi Sâsâiac received a BA in translation and interpreting and an MA in European Studies from Alexandru Ioan Cuza. University of Iași. He has recently completed his doctoral studies at the same university with a thesis on the translation of travel writings, with Romania as a case in point. His professional experience includes an Erasmus mobility at Université Catholique de l'Ouest, Angers, as well as the coordination of the Business English and French seminars for beginners at the Vocational College for Economists and Business Assistants in Novo Mesto, Slovenia. His fields of interest comprise journalistic translation and the translation of Romania's images as reflected in the English-language literature. His recent publications include National Images in the Media and in Travel Writing (2015) and Projections of Romania in Anglophone Travel Books in the Period Between 1850 and 1940 (2014). 